\title{
$P$-Nitrobenzenesulfinyl Chloride
}

$$
\begin{aligned}
& \text { 提案者 大饗 茂, 井倉勝弥太, 嶋 野泰 尚 } \\
& \text { (大阪市立大学工学部) }
\end{aligned}
$$

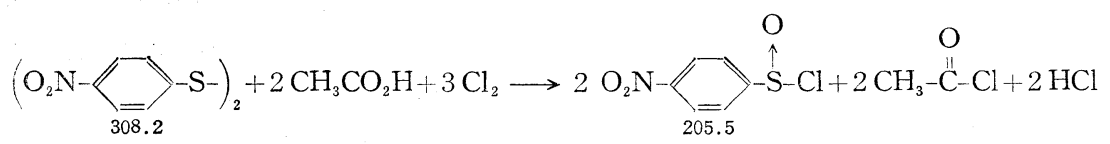

\section{I. 製 法}

容量 $1 l$ の三ツロフラスコに温度計, 還流冷却器, 塩素ガス導入管を取り付け, $p, p$-Dinitrodiphenyl Disulfide $50 \mathrm{~g}$ $(0.162 \mathrm{~mol})$ ，脱水精製した酢酸 $19.5 \mathrm{~g}(0.325 \mathrm{~mol})$ (注意 1$)$ ，無水クロロホルム $500 \mathrm{cc}$ を入れて $-5 \sim 10^{\circ} \mathrm{C}$ (注意 2 ) に冷却しながら乾燥塩素ガスを導入する。最初溶液は $p$-Nitrobenzenesulfenyl Chloride $\left(\mathrm{O}_{2} \mathrm{NC}_{6} \mathrm{H}_{4} \mathrm{SCl}\right)$ の生成 により赤黄色になるがこれはしだいに酢酸と反応して塩化水素を発生し, 目的の p-Nitrobenzenesulfinyl Chloride と塩化アセチルになり, 溶液は淡黄色に変ってゆく。約 1 時間程塩素ガスを導入し, 塩化水素の発生が完全に見られな くなって反応は完了する。つぎにクロロホルムおよび塩化アセチルを常温減圧で留去すると残留物として微黄色の $p-$ Nitrobenzenesulfinyl Chloride の結晶が得られる。

収量 $55 \sim 63 \mathrm{~g}\left(82.5 \sim 94.4 \%\right.$ ), $\mathrm{mp} 58 \sim 60^{\circ} \mathrm{C}$ (注意 3,4 )

\section{II. 注 意事 項}

(1) 酶酸はできるだけ正確に Disulfide に対して 2 倍モルを用いる。

(2) この温度範囲以上では Sulfenyl Chloride になって目的の Sulfinyl Chlorideが得られない場合もある。

（3）得られた Sulfinyl Chloride は再結晶すると分解し易いのでそのまま使用する。

（4） Sulfinyl Chloride は湿気に会うと簡単に分解するので五酸化リンデシケーター中に保存する。

\section{III. 性質}

ベンゼン，クロロホルム，エーテル等の溶媒によく溶ける。アセトンと反応して $\mathrm{O}_{2} \mathrm{NC}_{6} \mathrm{H}_{4} \mathrm{SOCH}_{2} \mathrm{COOH}_{3}$ (mp66〜 $\left.67^{\circ} \mathrm{C}\right)$ を生じ，これは確認に用いられる11。

\section{IV. 本法の利点}

ここにのベた合成法以外に Sulfinic Acid に塩化チオニルを作用させる方法2), 酢酸の代りに水またはメタノールを用 いた例 ${ }^{3}$ もある。Disulfide の代りにメルカプタンを用いても同じ結果が得られている。なおここで用いた合成法は Douglass らの方法(4比よるものである。

1) S. Oae, K. Ikura, Bull. Chem. Soc. Japan 391309 (1966)

2) D. Barnard, E. Percy, J. Chem. Soc. 1667 (1962)

3) I.B. Douglass, B.S. Farah, J. Org. Chem. 22526 (1957)

4) I.B. Douglass, D.R. Poole, J. Org. Chem. 23330 (1958)

\section{Phenylpropiolonitrile}

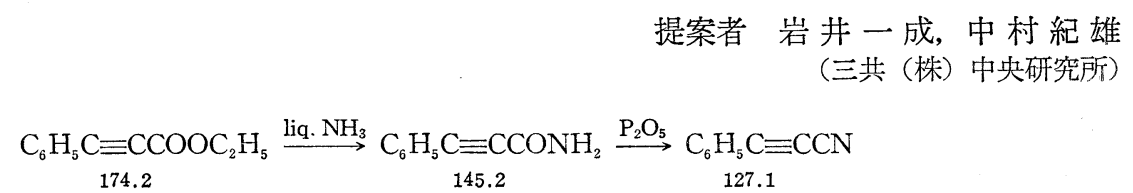

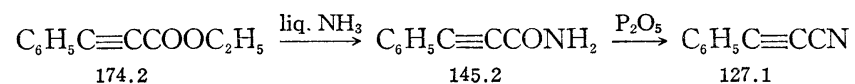

\section{I. 製 法}

カキマゼ機, 温度計, 水酸化カリウム管（注意 1 ）および滴下漏斗をつけた $500 \mathrm{ml}$ 三ツロフラスコに液体アンモニ ア $300 \mathrm{~m} l$ をとり，ドライアイスーアセトン浴で内温を $-45 \sim-50^{\circ} \mathrm{C}$ に保ち，かきまぜながら ethylphenylpropiolate $30.2 \mathrm{~g}(0.173 \mathrm{~mol})$ を約 15 分間で滴下したのち，この温度で 18 時間かきまぜる。冷却浴をとり去って徐々にアンモニ アを留去し, 最後に減圧下でエタノールを留去する。残った結晶をロ取し, ヘキサンで洗う。 $\mathrm{mp} 104 \sim 106^{\circ} \mathrm{C}$ の白色 結晶のアミド $23.0 \sim 24.5 \mathrm{~g}(92 \sim 96 \%)$ が得られる。つぎに $300 \mathrm{ml}$ ナス型フラスコに細かいケイ砂（注意2）22 $\mathrm{g}$ 